\title{
АЛГОРИТМ ВПРОВАДЖЕННЯ МЕТОДІВ ОЦІНЮВАННЯ ЕКОСИСТЕМНИХ ПОСЛУГ
}

\author{
ALGORITHM OF IMPLEMENTATION \\ OF ECOSYSTEM SERVICES EVALUATION METHODS
}

\author{
Ільїна Марія Володимирівна \\ доктор економічних наук, старший науковий співробітник, \\ ДУ «Інститут економіки природокористування та сталого розвитку \\ Національної академії наук України» \\ ORCID: https://orcid.org/0000-0002-5555-1614 \\ Шпильова Юлія Борисівна \\ доктор економічних наук, старший науковий співробітник, \\ ДУ «Інститут економіки природокористування та сталого розвитку \\ Національної академії наук України» \\ ORCID: https://orcid.org/0000-0003-0220-0041 \\ Ilina Maria, Shpylova Yuliia \\ Institute of Environmental Economics and Sustainable Development \\ of the National Academy of Sciences Ukraine
}

\begin{abstract}
У статті досліджено особливості впровадження методів оцінювання екосистемних послуг у систему управління природними ресурсами для сталого розвитку територій. Визначено етапи фрормування алгоритму впровадження методів оцінювання екосистемних послуг та здійснено їх детальний аналіз. Розглянуто міжнародні підходи до впровадження методів екосистемного оцінювання; обґрунтовано зв'язок основних напрямів удосконалення чинного законодавства України з метою впровадження екосистемного підходу у систему природокористування з цілями сталого розвитку. Описано інституційне забезпечення оцінки екосистемних активів та послуг для управління природокористуванням і соціально-економічним розвитком. Запропоновано концептуальну схема розробки алгоритму впровадження методів оцінювання екосистемних послуг у систему управління природними ресурсами на місцевому рівні.
\end{abstract}

Ключові слова: екосистема, екосистемна послуга, екосистемна оцінка, екосистемний актив, метод оцінки.

В статье исследованы особенности внедрения методов оценки экосистемных услуг в систему управления природными ресурсами для устойчивого развития территорий. Определены этапы формирования алгоритма внедрения методов оценки экосистемных услуг и проведен их детальный анализ. Рассмотрены международные подходы к внедрению методов экосистемного оценивания; обоснована связь основных направлений усовершенствования действующего законодательства Украины с целью внедрения экосистемного подхода в систему природопользования с целями устойчивого развития. Описано институционное обеспечение оценки экосистемных активов и услуг в систему управления природопользованием и социально-экономическим развитием. Предложена концептуальная схема разработки алгоритма внедрения методов оценки экосистемных услуг в систему управления природными ресурсами на местном уровне.

Ключевые слова: экосистема, экосистемная услуга, экосистемная оценка, экосистемный актив, метод оценки.

After the decentralization reform in Ukraine territorial communities have received additional rights to use inside natural resources. That enabled them to be not only consumers of ecosystem services but also the suppliers. It moves communities to implement methods for assessing ecosystem services since it help them to preserve ecosystems and use resources in better way. Establishment of payments for ecosystem services favour communities to have better living surrounding, provide financial capacity and prevent environmental conflicts. The economic effect of the ecosystem services assessment implementation is it reduces the cost of environmental protection measures. Theoretical and methodological principles of forming the algorithm evaluating ecosystem services should be studied comprehensively. The goal of the article is to develop the algorithm for the local level in order to provide sustainable development of territories. The elaborated algorithm includes the following elements: substantiation of the methods 
of ecosystem assets and services estimation; fixing the relation with the Sustainable Development Goals (by areas - water, soil resources, protected areas, waste management, assimilation potential); identification of institutions implementing the assessment methods (central, regional and local authorities governing the nature management and socio-economic development); depiction of ways to improve the work of nature management authorities due to introduction of ecosystem assets and services assessment methods; application of toolkits to implement the evaluation methods (i.e. recommendations for the development of policy papers, strategies, programs, and plans); institutional support of the assessment procedures. Also it is important to provide the information support for the process of ecosystem services assessment at the national, regional and local levels. It is offered to introduce special statistical reporting (for enterprises that relate to natural resources use) and develop e-platforms (like AERIS or the GEF Depository). It will help stakeholders to assess ecosystems themselves or verify the data.

Keywords: ecosystem, ecosystem service, ecosystem assessment, ecosystem asset, assessment method.

Постановка проблеми. Еколого-економічна доцільність впровадження методів оцінювання екосистемних послуг як інноваційного механізму організації взаємодії між економічними суб‘єктами, рекомендації щодо шляхів інституціалізації платежів, аналіз конкретних прикладів їх застосування сприятимуть подальшому науковому опрацюванню проблеми збереження екосистем та підвищення есрективності використання їх ресурсів. Практичне значення оцінювання сприятиме підвищенню якості середовища життєдіяльності територіальних громад, посиленню їх фрінансової спроможності та попередженню екологічних конфрліктів. Особливого значення це набуває з огляду на реформу децентралізації влади, в результаті якої громади отримали розширені права на використання природних ресурсів. Це дало їм змогу бути не лише споживачами екосистемних послуг, але і їх постачальниками. Економічна значущість полягає у підвищенні ефективності використання природних ресурсів та скороченні витрат на природоохоронні заходи.

Аналіз останніх досліджень і публікацій. В останні десятиліття значна кількість наукових досліджень 3 економіки природокористування й економічної географрії присвячена вивченню різноманітних аспектів фрункціонування екосистем, розробці і впровадженню екосистемного підходу в управління природокористуванням. Сучасні вітчизняні вчені основну увагу приділяють концептуалізації екосистемних послуг (Н. Гавадзин, Л. Загвойська, І. Мельничук), їх детальній класифрікації та систематизації (Н. Дегтяр, $€$. Мішенін, Н. Олійник), методології оцінювання (І. Сотник, Т. Горобченко). Ці та інші проблеми, що стосуються екосистем, досліджують зарубіжні і вітчизняні вчені. Сучасними науковими школами економіки природокористування ґрунтовно розроблено інструменти, основані на платежах за використання природних ресурсів та забруднення навколишнього при- родного середовища. Варто відзначити праці О. Алимова, І. Бистрякова, С. Дорогунцова, Л. Мельника, Я. Олійника, М. Паламарчука, Л. Руденка, М. Хвесика та багатьох інших.

Виділення невирішених раніше частин загальної проблеми. Окремі теоретикометодологічні аспекти формування алгоритму впровадження методів оцінювання екосистемних послуг у систему управління природними ресурсами потребують додаткового дослідження. Це завдання узгоджується 3 положеннями Закону України «Про основні засади (стратегію) державної екологічної політики України на період до 2030 року» та Цілями сталого розвитку України до 2030 року. Законом зазначено, що метою державної екологічної політики $є$ запровадження екосистемного підходу до всіх напрямів соціальноекономічного розвитку України, збереження та відновлення природних екосистем. Розвиток екосистемних послуг створить можливості для сталого розвитку суспільства, а біологічне різноманіття України, яке надає екосистемні послуги, до 2030 року повинно бути збережено, оцінено і відновлено.

Формулювання цілей статті (постановка завдання). Метою статті $\epsilon$ розробка алгоритму оцінювання екосистемних послуг для впровадження у систему управління природними ресурсами на локальному рівні з метою забезпечення сталого розвитку територій.

Виклад основного матеріалу дослідження. Формування алгоритму впровадження оцінки екосистемних послуг у систему управління природними ресурсами включає такі етапи:

- обґрунтування мети впровадження методів оцінювання екосистемних активів та послуг в управління природокористуванням;

- визначення ролі науково-практичного забезпечення впровадження методів оцінювання в практику управління;

- обґрунтування зв'язку Цілей сталого розвитку для України з екологічною ситуацією 
(за напрямами - водні, ґрунтові ресурси, природоохоронні території, поводження 3 відходами, асиміляційний потенціал), що актуалізує впровадження методів оцінювання екосистемних активів у вітчизняну практику управління природокористуванням;

- визначення об'єктів впровадження методів оцінювання (центральних, регіональних та місцевих органів управління природокористуванням та соціально-економічним розвитком) на всіх рівнях (громада, регіон, країна) та за галузями;

- обґрунтування перспектив удосконалення роботи органів управління природокористуванням за рахунок впровадження методів оцінювання екосистемних активів та послуг;

- представлення предмету впровадження методів оцінювання екосистемних активів та послуг (методичні рекомендації з розробки стратегій, програм, планів розвитку, схем обов'язкових, добровільних платежів, проектів нормативно-правових актів тощо);

- соормування етапів інституційного забезпечення оцінювання екосистемних активів та послуг для управління природокористуванням і соціально-економічним розвитком (розробка і впровадження методик оцінювання, визначення розмірів екологічних платежів на основі екосистемного підходу, впровадження фрінансових інструментів стимулювання суб'єктів господарювання до ведення економічної діяльності на екосистемних засадах і т.д.);

- визначення актуальних завдань, що стоять перед суспільством на шляху впровадження методів оцінювання екосистемних активів та послуг у роботу органів влади різних рівнів [1].

У більшості суспільствознавчих досліджень під впровадженням розуміють здійснення на практиці зацікавленими органами чи особами висновків і практичних рекомендацій науковців, запропонованих і обґрунтованих ними як результат відповідних теоретичних або емпіричних наукових розробок [2]. Тому впровадження певних інструментів або рекомендацій (методологія оцінки екосистемних послуг $\epsilon$ одним із прикладів таких розробок) покликане забезпечити представникам органів влади та місцевого самоврядування виконання організаційної і регуляторної функцій. У випадку захисту екосистем та збереження біорізноманіття такі фрункції стосуються регулювання інтенсивності й особливостей використання екосистемних послуг та організації процесу управління ними. Управління екосистемами та їх послугами тісно пов'язане з природокористуванням як організованою й інституціолізованою діяльністю з охорони довкілля та раціонального й ефрективного використання природних ресурсів.

Оцінювання екосистемних послуг та активів може бути обов'язковою вимогою для затвердження політичних документів - стратегій, планів розвитку регіону або громади; для участі у міжнародних та місцевих конкурсах проектів технічної допомоги, грантової підтримки, комерційних конкурсах з приватизації чи оренди об‘єктів державної або комунальної власності. У цьому випадку вимоги щодо процедури проведення і ухвалення екосистемної оцінки можуть бути подібними до обов'язкової оцінки впливу проектів або господарської діяльності на довкілля. Слід зауважити концептуальну відмінність екологічної та екосистемної оцінки: перша має на меті збереження, захист довкілля та подолання його забруднення, друга - підвищення ефективності природокористування, підтримку місцевої економіки та позитивний вплив на рівень добробуту мешканців територій розташування екосистем.

Обов'язковість екосистемного оцінювання має бути закріплена нормативними актами та мати єдиний методологічний супровід (методологічні рекомендації, посібник), який уможливить контроль якості, точності, відповідності оцінки, її порівняння, а також моніторинг. Враховуючи методологічну складність екосистемного оцінювання, нормативними актами мають бути визначені спеціально уповноважені організації, уповноважені здійснювати таку оцінку, порядок їх сертисрікації.

Екосистемне оцінювання може бути добровільним і здійснюватися органами влади, залученими науковими організаціями, громадськими об'єднаннями 3 метою удосконалення екологічної політики, управління природокористуванням, організації схем платежів за екосистемні послуги. Удосконалення екологічної політики на основі екосистемного оцінювання може відбуватися шляхом ухвалення рішень зменшити навантаження на екосистему, якщо її стан незадовільний, вона деградує або виснажена, розробки заходів 3 поліпшення стану екосистеми. Управління природокористуванням на основі екосистемного оцінювання включає регулювання використання природних ресурсів в межах оціненої екосистеми: відмова від використання або скорочення промислового, побутового чи навіть індивідуального використання певних 
видів ресурсів, підвищення вартості використання ресурсів (у т.ч. у вигляді штрасрів, плати за ліцензування), стимулювання заміни споживання одних ресурсів іншими (у т.ч. за рахунок пільг та субсидій).

Організація схем платежів за екосистемні послуги на основі екосистемного оцінювання дає змогу місцевим мешканцям та органам влади більш точно визначити природноресурсний потенціал належної їм території, ступінь його залучення у господарську діяльність, власні можливості наповнення місцевого бюджету за рахунок регулювання економічної діяльності, здійснюваної за рахунок екосистемних послуг. Саме екосистемна оцінка дає змогу громаді ухвалити рішення про доцільність участі у схемах платежів за екосистемні послуги, а також визначити екологічні та фрінансові умови такої участі. У випадку добровільного оцінювання екосистемних послуг методологічні підходи можуть варіюватися залежно від мети оцінювання, вимог щодо точності оцінки, квалісрікації залучених сторін.

В Україні 3 метою здійснення та впровадження оцінки біорізноманіття й екосистемних послуг доцільно розвивати співпрацю 3 відповідними міжнародними організаціями наприклад, з Міжурядовою науково-політичною платформою $з$ біорізноманіття та екосистемних послугах (англ. - IPBES), глобальною ініціативою 3 економіки екосистем та біорізноманіття (TEEB), проектом зі сприяння картографуввання екосистемних послуг для цілей політики й ухвалення рішень (англ. ESMERALDA), спеціальною робочою групою ЄК щодо картографрування та оцінки екосистемих послуг (MAES). Важливо, аби таке оцінювання було міждисциплінарним і враховувало міжнародні підходи та системи оцінювання.

Основні напрями удосконалення чинного законодавства України з метою впровадження екосистемного підходу у систему природокористування включають:

-у сорері водокористування: впровадження концепції збереження біорізноманіття; інтеграція екосистемного підходу до управління сорерою; розробка і реалізація заходів на виконання Цілі сталого розвитку 14. Збереження та раціональне використання океанів, морів і морських ресурсів в інтересах сталого розвитку (до 2030 р. скорочення частки скидів забруднених стічних вод у загальному обсязі скидів до морського середовища до 5\%, зростання площі територій та об'єктів ПЗФ приморських областей до 10\% від терито- рії приморських областей, збільшення площі територій та об'єктів ПЗФ в акваторії Чорного та Азовського морів до 752 тис. га) [3];

- у ссрері землекористування: впровадження концепції сталого землекористування, збереження біоресурсів та природних екосистем; до 2030 р. скорочення частки площі орних земель (ріллі) у загальній території країни до 47\%, збільшення частки площі сільськогосподарських угідь екстенсивного використання (сіножатей, пасовищ) у загальній території країни до 15,8\% згідно з Ціллю сталого розвитку 15. Захист та відновлення екосистем суші та відповідними індикаторами для України; забезпечення застосування екосистемного підходу під час ухвалення рішень щодо землевідведення, зміни цільового призначення земельних ділянок; розробка і реалізація заходів управління агроландшасртами на екосистемних засадах;

- у сорері лісокористування: впровадження концепції сталого лісокористування, збереження біоресурсів та природних лісових екосистем; зростання до 2030 р. лісистості території країни до $20 \%$ згідно 3 Ціллю сталого розвитку 15. Захист та відновлення екосистем суші;

- у ссрері збереження біорізноманіття: визнання об‘єктів тваринного і рослинного світу невід'ємними елементами природних екосистем, а їх існування - умовами збереження екологічної рівноваги; розробка і реалізація заходів, спрямованих на особливу охорону та захист об“єктів, що знаходяться під загрозою зникнення; забезпечення транскордонного екологічного співробітництва з метою охорони фрлори та фрауни;

- у ссрері охорони атмоссрерного повітря: впровадження заходів, спрямованих на зменшення викидів; стимулювання впровадження технологій зеленої енергетики; скорочення викидів парникових газів до рівня 1990 р. згідно з Ціллю сталого розвитку 13. Пом'якшення наслідків змін клімату.

На національному рівні впровадження оцінки екосистемних послуг доцільно здійснювати 3 урахуванням вимог відповідних міжнародних документів та участі в міжнародних договорах. Наприклад, одним із завдань Стратегії $€ C$ щодо біорізноманіття $€$ поліпшення стану екосистем за рахунок екологічної інсрраструктури та відновлення принаймні $15 \%$ деградованих екосистем. Для досягнення цієї мети Стратегія встановлює основні етапи оцінки послуг екосистем: ідентифрікацію таких послуг, їх картограсрування, кількісне 
або якісне оцінювання, аналіз перспектив впровадження результатів оцінювання у систему управління. Для виконання цих заходів створено інформаційну базу щодо екосистем та їх послуг, покладено на держави-члени ЄС зобов'язання здійснювати картографування та оцінку послуг, ухвалено підходи до визначення екосистем, пріоритетних для відновлення або поліпшення [4].

Програма 3 виконання Стратегії біорізноманіття період до 2030 року передбачає низку заходів, на основі яких додатково визначаються такі етапи впровадження оцінки екосистемних послуг у систему управління природокористуванням: визначення прямих і непрямих сракторів поточної втрати біорізноманіття; оцінка впливу та взаємовпливу на стан екосистем, які забезпечують збереження біорізноманіттям, споживання водних ресурсів, фуункціонування сільського, лісового і рибного господарства, охорону здоров'я відповідних галузевих політик; розробка і впровадження методологічних підходів до оцінювання ефективності політик в частині збереження біорізноманіття.

Заходи з ухвалення рішень, що стосуються управління екосистемами та використання їх послуг, включає ідентифрікацію та картографрування екосистем, їх фрункцій та послуг; визначення економічних, екологічних, соціальних вигод від використання послуг; визначення їх вартості (біофрізична, соціальна, економічна, фрінансова оцінка); залучення та врахування інтересів сторін, зацікавлених у використанні екосистем та їх послуг; врахування інституціональних і нормативно-правових обмежень та умов, що визначають використання екосистемних послуг; ухвалення рішень щодо використання послуг, моніторинг впливу ухвалених рішень на довкілля та стан екосистем.

Алгоритм оцінювання екосистемних послуг 3 метою його впровадження у систему управління природокористуванням включає етап визначення екосистем та екосистемних послуг, що будуть оцінюватися. Найчастіше для подальшого оцінювання екосистемних послуг обирають лише пріоритетні - ті, на які спрямовуватимуться заходи з управління природокористуванням. Мова йде про найбільш деградовані екосистеми, стан яких потребує негайного реагування, екосистемні послуги, актуальні для міжнародної спільноти - наприклад, здатність зв'язувати вуглець для боротьби зі змінами клімату, транскордонний характер переносу забруднень атмоссрерного повітря та водних ресурсів, міграція тварин (рис. 1).
3 метою первинної типології екосистем доцільно застосувати найбільш поширений підхід, розроблений MAES, а саме поділ на урбо-, агро-, природні, прісноводні та морські екосистеми. Такий підхід не лише збігається з застосовуваним Стратегією $€ \mathrm{C} 3$ біорізноманіття, але й низкою директив, а також дає змогу оцінювати досягнення Цілей Сталого Розвитку.

Кількісне та якісне біофрізичне, екологічне й економічне оцінювання екосистемних послуг включає визначення та отримання первинної інформації (забезпечують аналіз статистичних джерел, польові дослідження, звіти геоорізичних лабораторій та ГІС); вибір методів оцінювання (кількісне та якісне оцінювання екосистемних послуг здійснюється 3 використанням умовної оцінки, аналізу витрат і вигод, гедоністичного ціноутворення, витрат на відновлення і т.д. [4]); оцінку стану, тенденцій використання, сталості, запасу міцності екосистем; оцінку впливів на стан екосистем та послуг; вибір одного зі способів упровадження оцінки екосистемних послуг у процес ухвалення рішень; моніторинг результатів реалізації політики.

Одним із найбільш очевидних та зрозумілих з економічної точки зору інструментів застосування концепції екосистемних послуг загалом та оцінки їх вартості $€$ організація платежів за екосистемні послуги [5]. 3 цією метою зусилля відповідних органів влади мають бути зосереджені навколо розроблення рекомендацій щодо збереження екосистем та відновлення їх функцій; фрормування ринку екосистемних послуг з урахуванням прав власності та перспектив капіталізації послуг; моніторингу біорізноманіття; визначення грошової вартості основних екосистемних послуг або створення інорормаційної платорорми для приблизного оцінювання вартості (на зразок Депозитарія для вивчення економічної оцінки екосистемних послуг, розробленого Глобальним екологічним фондом) з метою раціоналізації рішень на основі впровадження схем платежів за послуги; впровадження вимоги оцінювання екосистемних послуг та врахування їх вартості під час розробки планів національного, регіонального, територіального розвитку. Важливим $€$ залучення до управління екосистемними послугами усіх зацікавлених сторін 3 метою уникнення консрліктів - насамперед між постачальниками послуг та їх бенесріціарами; створення єдиного центрального органу з управління екосистемними послугами, підпорядкованого Міністерству захисту 


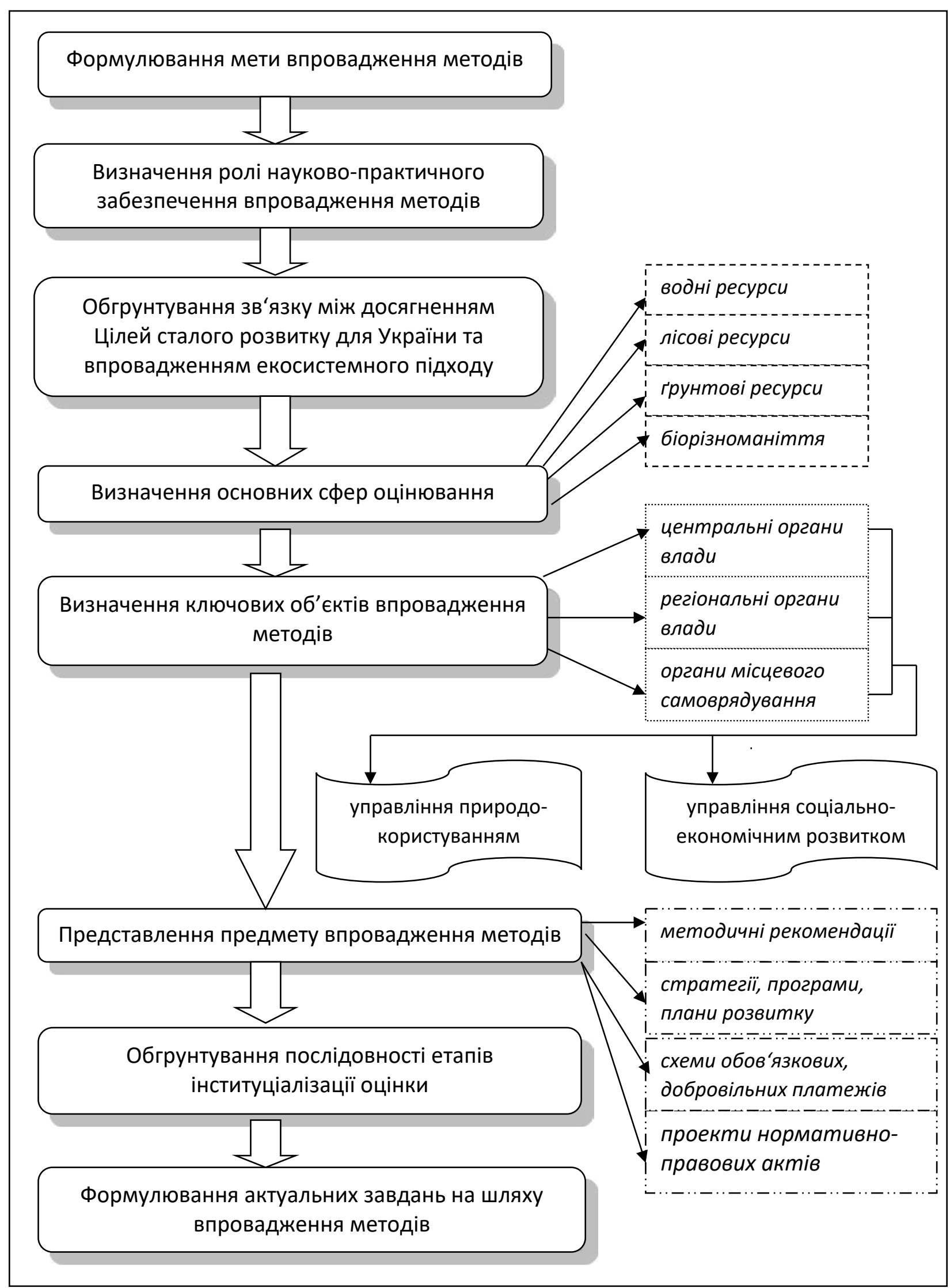

Рис. 1. Алгоритм впровадження методів оцінювання екосистемних послуг в управлінні природними ресурсами

Джерело: розроблено авторами 
довкілля України, на зразок нині діючих державних агентств лісових, водних, земельних ресурсів [6].

Створення національної системи моніторингу, оцінки й обліку екосистемних послуг забезпечить практичне врахування цінності екосистем при розробці й ухваленні рішень, стратегічних документів та нормативно-правових актів. Невиконання цього завдання унеможливлює управління природокористуванням на екосистемних засадах, призводить до недоотримання громадами платежів за використання належних їм екосистем, суперечить взятим Україною на себе зобов'язань з виконання Цілей сталого розвитку. Оцінювання екосистемних послуг потребує міждисциплінарних зусиль, а інфрормаційне забезпечення процесу оцінювання - міжвідомчої координації [6]. Комплексна оцінка екосистемних послуг повинна складатися 3 біофрізичної та економічної, кількісної та якісної. 3 методологічної точки зору для оцінки екосистемних послуг на національному рівні доцільно застосовувати методологію TEEB, враховуючи рекомендації ESMERALDA, MAES та ARIES, для класифікації екосистемних послуг - Загальну міжнародну класифрікацію екосистемних послуг (CICES).

Висновки і подальші перспективи дослідження. Оцінювання екосистемних послуг $\epsilon$ складним, суперечливим та неоднозначним процесом, що має безліч умов 3 методологічної точки зору, а також обмежень через брак знань та інформації. Концептуально основна складність оцінювання економічної вартості екосистемних послуг пов'язана з тим, що їх реальна (соціальна, економічна та екологічна) вартість зазвичай набагато перевищує економічну оцінку використання відповідних природних ресурсів.

Актуальним завданням для України $\epsilon$ інорормаційне забезпечення процесу оціню- вання екосистемних послуг на національному, регіональному та локальному рівнях. 3 цією метою доцільно впроваджувати спеціальну статистичну звітність (для підприємств, чия діяльність особливо пов'язана з природокористуванням) та розробляти електронні інорормаційні платорорми (подібні до AERIS або Депозитарію ГЕФ), які даватимуть можливість зацікавленим сторонам здійснювати екосистемну оцінку самостійно або перевіряти достовірність використовуваних даних.

Всебічне впровадження екосистемного підходу в практику управління природокористуванням, захист екосистем та екосистемних послуг, широке застосування екосистемної оцінки для контролю господарської діяльності (подібно до обов'язкової оцінки екологічного впливу) є неможливими без належного інституціонального забезпечення. Створення при Міндовкілля України спеціального органу, відповідального за реалізацію політики у сорері захисту екосистем, збігатиметься з закордонною практикою, відповідатиме міжнародним вимогам, сприятиме розв'язанню нагальних екологічних проблем та досягненню Цілей сталого розвитку.

Враховуючи складність оцінювання екосистемних послуг та брак первинної інорормації для застосування відповідних методик, для потреб органів місцевого самоврядування доцільно розробити адаптований (спрощений) методологічний підхід до оцінки таких послуг. Це дасть змогу більш широко застосовувати екосистемний підхід при плануванні стратегій місцевого розвитку, у господарській діяльності та для екологічного контролю. Адаптовані методики мають забезпечувати отримання принаймні наближених оцінок екосистемних послуг, що даватиме підстави для оперативного корегування політики управління природокористуванням на місцевому рівні.

\section{СПИСОК ВИКОРИСТАНИХ ДЖЕРЕЛ:}

1. Ільїна М.В., Шпильова Ю.Б. Екосистемні послуги як інструмент екологічно орієнтованої організації сільського простору. Бізнес-навігатор. 2020. № 2(58). С. 54-58.

2. Зуєв В. Поняття впровадження в сучасному філософському дискурсі / Національний педагогічний університет імені М.П. Драгоманова. URL: https://ird.npu.edu.ua/files/zyev.pdf

3. Цілі сталого розвитку: Україна. Національна доповідь / Міністерство економічного розвитку і торгівлі України. 2017. 176 с.

4. Розроблення науково-методичних засад щодо оцінки екосистемних послуг з врахуванням необхідності виконання рішень міжнародних природоохоронних договорів. Звіт про науково-технічну продукцію за договором № 74/19 від 29 серпня 2019 р. / Міністерство захисту довкілля та природних ресурсів України. URL: https://mepr.gov.ua/files/docs/Bioriznomanittya/V1\%201.pdf

5. Ільїна М.В., Шпильова Ю.Б. Значення екосистемних активів для забезпечення сталого розвитку територій. Східна Європа: економіка, бізнес та управління. 2021. Вип. 4(31). С. 93-98. 
6. Бурковський О.П., Василюк О.В. Концепція створення державного агентства екосистемних послуг. Від заповідання до збалансованого природокористування : матеріали міжнародної наукової конференції (20-22 березня 2013 р., м. Донецьк). Донецьк : Донецький національний університет, 2013. С. 176-179.

\section{REFERENCES:}

1. Ilina M., Shpyliova Y. (2020) Ekosystemni poslugy yak instrument ekologichno orientovanoyi organizatsii silskogo prostoru [Ecosystem services as the instrument of environmentally oriented establishment of rural areas]. Biznes-navigator, no. 2(58), pp. 54-58.

2. Zuyev V. Poniattya vprovadzhennia v suchasnomu filosofskomu dyskursi [The concept of implementation in modern philosophical discourse]. National Pedagogical University named after MP Drahomanov. Retrieved from: https://ird.npu.edu.ua/files/zyev.pdf (in Ukrainian)

3. Tsili staloho rozvytku: Ukrayina. Natsionalna dopovid (2017) [Sustainable development goals: Ukraine. National Report]. Ministerstvo ekonomichnoho rozvytku i torhivli Ukrayiny. (in Ukrainian)

4. Rozroblennya naukovo-metodychnykh zasad shchodo otsinky ekosystemnykh posluh vrakhuvannyam neobkhidnosti vykonannya rishen mizhnarodnykh pryrodookhoronnykh dohovoriv [Development of scientific and methodological principles for the assessment of ecosystem services, taking into account the need to implement the decisions of international environmental treaties]. Zvit pro naukovo-tekhnichnu produktsiyu za dohovorom № 74/19 vid 29 serpnya 2019. Ministerstvo zakhystu dovkillya ta pryrodnykh resursiv Ukrayiny. Retrieved from: https://mepr.gov.ua/files/docs/Bioriznomanittya/V1\%201.pdf (in Ukrainian)

5. Ilina M., Shpylioba Y. (2021) Znachennia ekosystemnyh aktyviv dlia zabezpechennia stalogo rozvytku terytoriy [Meaning of ecosystem assets for provision of the sustainable development of areas]. Shidna Yevropa: ekonomika, biznes ta upravlinnia, no. 4(31), pp. 93-98.

6. Burkovskyy O.P., Vasylyuk O.V. (2013) Kontseptsiya stvorennya derzhavnoho ahentstva ekosystemnykh posluh [The concept of creating a state agency of ecosystem services]: Materialy Mizhnarodnoyi naukovoyi konferentsiyi «Vid zapovidannya do zbalansovanoho pryrodokorystuvannya» - Proceedings of the International Scientific Conference «From the commandment to sustainable nature management» (Donetsk 20-22 bereznya). Donetsk. (in Ukrainian) 